\title{
A problematização do conhecimento científico
}

\author{
Diana Paula de Souza Rego Pinto Carvalho \\ https://orcid.org/0000-0001-9485-5015 | E-mail: dianarego@uern.br
}

\section{Qual o método do meu projeto de pesquisa?}

Esse é o primeiro questionamento que o orientador escuta do estudante. Eles estão sempre preocupados com a técnica de coleta de dados, se o seu projeto será qualitativo ou quantitativo. Às vezes, até nos rotulamos: "sou uma professora que só trabalha com estudos quantitativos". A partir daí, estudantes que simpatizam com esse pensamento buscam nossa orientação. Até que ponto o pesquisador define o método a ser desenvolvido em uma pesquisa? Como delimitar o seu percurso metodológico?

A partir dessas reflexões, surgem outros questionamentos sobre a ciência. É muito comum ouvir críticas acerca dos avanços científicos. A ciência proporciona resultados positivos para a sociedade ou é apenas mais um instrumento de poder? Por que razão precisamos todos saber algo sobre a ciência?

Esses questionamentos perpassam por várias décadas e em vários contextos diferentes, ainda assim, são atuais e pertinentes. Contribuir para a formação dos alunos com este embasamento críticoreflexivo terá como efeito elevar o nível de seu aproveitamento escolar, aprendendo a ler e entender o que o pesquisador está contando, ser ativo nas atividades acadêmicas, organizando metodicamente o seu pensamento na busca da solução de seus problemas. A longo prazo, será possível aplicar a pesquisa em seu campo de trabalho e no exercício de sua profissão para continuar aprimorando seu desempenho e elevando o seu nível de rendimento e entendimento.

O que queremos, portanto, é esclarecer, primeiramente, que o método da pesquisa não é delimitado simplesmente por preferências teóricas, mas que existe um contexto acerca do pesquisador e de todas as variáveis que envolvem aquele tema que precisam ser considerados. E além disso, destacar que o pesquisador precisa ter domínio da metodologia, que o tema precisa ser bem delimitado e contextualizado para só assim, definir o método científico do projeto.

\section{Porque estudar o método científico?}

A pesquisa científica é considerada o melhor método, para adquirir conhecimento confiável, desenvolvido pelos seres humanos. As perguntas que os pesquisadores fazem e o método que usam para responder seus questionamentos surgem da visão do pesquisador de como o mundo funciona.

É o que chamamos de paradigma, a visão global, uma perspectiva geral sobre as complexidades do mundo. Nesse contexto, é importante que o pesquisador tenha um mínimo de entendimento sobre a epistemologia do conhecimento, que consiga refletir sobre a realidade, a abordagem que envolve os processos, como o objeto de estudo se relaciona com o pesquisador e quais os valores são pertinentes a esse objeto. 
Para Habermas (2002), não se trata de procurar modificar ou melhorar a situação da razão centrada no sujeito. O paradigma que representa o conhecimento de objetos deve ser substituído pelo paradigma do entendimento entre sujeitos capazes de falar e agir. No paradigma do conhecimento, o sujeito consciente se dirige a si mesmo como a entidades do mundo. No paradigma do entendimento, o ego ao falar e o alter ao tomar posição sobre este participam de uma relação interpessoal. Assim, o ego encontra-se em uma relação que, na perspectiva de alter, permite-lhe referir a si mesmo como participantes de uma interação.

Dessa forma, é importante perceber que conhecimento científico é produzido por indivíduos que pensam, sentem e fazem, e que há uma constante interação entre pensar, sentir e fazer. É preciso repensar a rígida sequência de passos que é ensinada no método científico, que começa com a observação e culmina em uma conclusão/descoberta (Moreira, 1993).

E para entender como as pesquisas se desenvolvem, como aquele resultado tem alta acurácia ou baixa significância ou ainda como refutaram aquela tese, é imprescindível o estudo do método, a metodologia. É preciso conhecer e praticar, só assim será possível a crítica aos resultados dos estudos.

Logo, faz-se necessário diferenciar alguns conceitos. Entenda que método vem do grego méthodos ( meta $=$ além de, após de + ódos $=$ caminho). Seguindo a sua origem, método é o caminho ou a maneira para chegar a determinado fim ou objetivo, distinguindo-se assim, do conceito de metodologia, que deriva do grego méthodos (caminho para chegar a um objetivo) + logos (conhecimento). Assim, a metodologia é o estudo do método. São os procedimentos e regras utilizados por determinado método. Portanto, o método científico é o caminho da ciência para chegar a um objetivo. A metodologia são as regras estabelecidas para o método científico (Richardson, 2017, p. 16).

Pois bem, agora que é possível entender que o percurso metodológico precisa ser estudado para ser delimitado, passamos a refletir sobre a seleção da melhor técnica de coleta de dados, da estratégia de análise mais adequada. E, pode até parecer filosófico, mas quem ou o que define o método a ser utilizado no projeto a ser desenvolvido é o problema de pesquisa. Os estudantes precisam compreender a importância de um problema de pesquisa bem delimitado, pois só assim será possível descrever de forma clara o que se pretende estudar, o objetivo a ser alcançado.

\section{A contribuição do método científico para a sociedade}

É necessário incluir em nossos estudos teóricos e práticos a capacidade de problematização, de contextualização, autonomia, criticidade e reflexão acerca dessas informações, para que assim consiga avançar com o conhecimento científico. O problema da pesquisa delimita o método, estabelece relações socioambientais com os conceitos científicos e tecnológicos.

Lakatos e Marconi (1982, p. 39-40) se referem a característica distintiva do método, de ajudar a compreender, no sentido mais amplo, não os resultados da investigação científica, mas o próprio processo de investigação.

Ao corroborar com esse pensamento, defende-se que o mesmo objeto pode ser estudado sobre diversas perspectivas, mas para que isso aconteça, o pesquisador precisa ter domínio do seu conteúdo, de todas as circunstâncias que podem influenciar. Uma maneira mais completa de encarar as gradações das diferenças entre as abordagens metodológicas, quantitativa e qualitativa, está nas suposições filosóficas básicas que os pesquisadores levam para o estudo, nas estratégias de pesquisa utilizadas em toda a pesquisa, por isso, justifica-se mais uma vez a importância dos conhecimentos epistemológicos acerca da ciência.

Dessa forma, tem-se alguns procedimentos técnicos que podem ajudar a delimitar o problema de pesquisa. Primeiro, é importante que seja um problema que chame atenção e que precise de resposta, o pesquisador precisa recompilar informações relacionadas ao problema, estudar possíveis relações entres as informações que possam contribuir e esclarecer o problema e propor diversas explicações (hipóteses). 
A partir desses procedimentos, o pesquisador compreende que a pesquisa representa uma forma de pensar, de analisar criticamente os vários aspectos do dia a dia do trabalho profissional; de formular princípios orientadores de um determinado procedimento; de desenvolver e testar novas teorias que contribuam para o avanço da sua profissão na sociedade.

Compreender a aplicação do método científico diante desses problemas aparentemente não científicos é fundamental para poder conhecer e transformar a realidade (Richardson, 2017, p. 17). Nesse contexto, é importante que o pesquisador tenha consciência de que o seu papel é manter essa inter-relação com a sociedade ao abordar os benefícios e riscos das descobertas científicas, as questões éticas a elas relacionadas, os interesses envolvidos, a origem dos recursos que financiam e os possíveis impactos econômicos, ambientais e sociais.

Atualmente, o maior desafio dos professores e pesquisadores é possibilitar que o aluno seja formado com essa capacidade de autonomia, criticidade, contextualização e problematização. Dessa forma, algumas considerações, pessoais e sociais, podem ser priorizadas e a pesquisa científica proporcionará um produto significativo, em seus aspectos culturais, sociais e tecnológicos que supera o ambiente acadêmico em que foi desenvolvida contribuindo para a cidadania e formação da educação científica.

\section{Referências}

Richardson, R. J. (2017). Pesquisa social: métodos e técnicas - 4 ed. rev., atual. E ampl., - São Paulo: Atlas. Moreira, M. A. (1993). Sobre o ensino do método científico. Caderno Brasileiro de Ensino Física, 10(2), 108-117. Lakatos, E. M., Marconi, M. A. (1982). Metodologia científica. São Paulo: Atlas.

Habermas, J. (2002). O discurso filosófico da modernidade. São Paulo: Martins Fontes. 